\title{
Laron syndrome
}

INSERM

\section{Source}

INSERM. (1999). Orphanet: an online rare disease and orphan drug data base. Laron

syndrome. ORPHA:633

Laron syndrome is a congenital disorder characterized by marked short stature associated with normal or high serum growth hormone $(\mathrm{GH})$ and low serum insulin-like growth factor-1 (IGF-I) levels which fail to rise after exogenous GH administration. 